\title{
ENZYMATIC CHARACTERIZATION OF Vibrio alginolyticus STRAINS ISOLATED FROM BIVALVES HARVESTED AT VENICE LAGOON (ITALY) AND GUANABARA BAY (BRAZIL)
}

\author{
Andrea LAfiSCA(1), Christiane Soares PEREIRA(2), Valério GIACCONE(1) \& Dalia dos Prazeres RODRIGUES (2)
}

\begin{abstract}
SUMMARY
The aquatic ecosystem is the natural habitat of microorganisms including Vibrio and Aeromonas genus which are pathogenic to human and animals. In the present investigation the frequency of these bacteria and the enzymatic characteristics of 34 Vibrio alginolyticus strains isolated from bivalves harvested in Venice Lagoon (Italy) and Guanabara Bay (Brazil) were carried out from November 2003 to February 2004. The mussels' samples were submitted to enrichment in Alkaline Peptone Water (APW) added with $1 \%$ of sodium chloride $(\mathrm{NaCl})$ and $\mathrm{APW}$ plus $3 \% \mathrm{NaCl}$ incubated at $37{ }^{\circ} \mathrm{C}$ for $18-24 \mathrm{~h}$. Following the samples were streaked onto TCBS Agar (Thiossulfate Citrate Bile Sucrose Agar) and the suspected colonies were submitted to biochemical characterization. Also, the Vibrio alginolyticus strains were evaluated to collagenase, elastase and chondroitinase production. The results showed the isolation of 127 microorganisms distributed as follows: 105 Vibrio strains such as V. alginolyticus (32.4\%), V. harveyi (19\%) and V. parahaemolyticus (7.6\%), 20 Aeromonas strains and two Plesiomonas shigelloides were the main pathogens isolated. We observed the production of the three enzymes from $V$. alginolyticus strains considered as the main virulence factors of the bacteria, especially in cases of human dermatological infection.
\end{abstract}

KEYWORDS: Vibrio spp.; Vibrio alginolyticus; Enzymatic Activities; Pathogenicity.

\section{INTRODUCTION}

The marine bivalve's consumption is an increased alimentary habit at coastal regions around the world. Therefore, mussels consumed without cooking or after an insufficient process of cooking may be at risk for humans because these animals are capable to retain pollutants and pathogenic bacteria in their organisms ${ }^{5,7}$.

The aquatic ecosystem is the natural habitat of microorganisms belonging to the Vibrio genus and the most known is Vibrio cholerae, the causative agent of cholera. Otherwise, many species are able to transmit intestinal or extra intestinal diseases to human. Amongst these last ones $V$. vulnificus, $V$. carchariae and $V$. alginolyticus are widely spread in the marine environment; both in closed seas, like the Mediterranean, and in oceans s,10,11. $^{5}$.

These bacteria have been found in water samples from marine environment, mussels, fish and their products. Since the end of the 80 s, the presence of these microorganisms was correlated to human infections. The infection sites (the medium ear, conjunctive membrane, open wounds) were hosting a complex microbial flora. Infections caused by Vibrio alginolyticus can present themselves as septicemic related to the ingestion of contaminated seawater or seafood products specially in patients as elders, children, carriers of diabetes mellitus or chronic hepatic pathologies ${ }^{1,3}$.

The cutaneous infections can be caused when wounds were in the presence of water where the bacterium is autochthonous. Often patients with dermatitis can develop septicemia from primary lesion (wounds infections). The symptomatology of dermatitis is the same to all Vibrio dermatopathogens and includes edema, erythema, and blisters with serum-hemorrhagic content, ulcers and necrosis of the affected area. In some cases, the lesion becomes deeper with sections of necrotizing fasciitis or osteomyelitis. The pathogenesis of these symptoms is not total elucidated, but diverse factors are included as the action of isoenzymes such as elastases, collagenases, DNAses, chondroitinases, gelatinases, lechitinases and keratinases. These enzymes have different functions: the collagenase enzyme is able to degrade conjunctive tissue and basal epithelial membrane is the key to cause extra intestinal pathology and dissemination to blood stream. The inability of some species, like the $V$. fluvialis, to degrade the components of the conjunctive tissue seems to limit its capacity to cause extra intestinal pathology. The concomitant lack of the keratinases in the majority of Vibrio species, and the ability to degrade the conjunctive tissue is consistent with their condition of opportunists' bacteria which need a primary lesion to invade the derma and hypodermic layers of the $\operatorname{skin}^{3,5,10,11}$.

(1) Università di Padova, Dipartimento di Sanità Pubblica, Patologia Comparata ed Igiene Veterinaria Agripolis, Viale dell’Università 16, Legnaro, Itália.

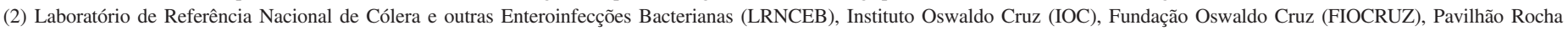
Lima, Avenida Brasil 4365, $3^{\circ}$ andar, sala 320, Manguinhos, 21045-900 Rio de Janeiro, RJ, Brasil.

Correspondence to: Christiane Soares Pereira, Tel./fax: +55.21.2270-6565, ramal 320. E-mail: chrisspm@ioc.fiocruz.br 


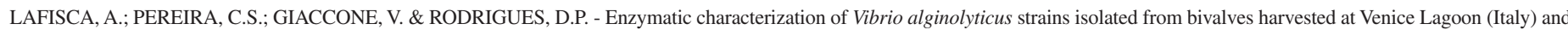
Guanabara Bay (Brazil). Rev. Inst. Med. trop. S. Paulo, 50(4): 199-202, 2008.

The decision to compare the bacteria isolated from mussels harvested in two distant geographical areas, Venice and Rio de Janeiro, was based on the same characteristics of these cities. In both we observed anthropogenic problems as chemical and microbiological pollution and the progressive increase of water temperature recorded in last years in consequence of global climate changes. Otherwise, we observed the increase of development activities associated to mollusk cultures and seafood consumption, particularly of the species: Mytilus galloprovincialis and Ruditapes semidecussatus in Venice Lagoon and Perna perna in Guanabara Bay ${ }^{4}$.

The aim of this research was evaluate the frequency of Vibrio alginolyticus isolated from bivalves mollusks harvested in Italy and Brazil and their enzymes (collagenases, elastases and chondroitinases).

\section{MATERIAL AND METHODS}

A total of 30 samples of bivalve mollusks were collected in Venice Lagoon between September and November 2003. Dipartimento di Sanità Pubblica, Patologia Comparata ed Igiene Veterinaria Agripolis, Università di Padova (Italia). The samples were composed by 200 adult mussels presenting their valves closed and commercial size (larger than $6 \mathrm{~cm}$ ). The mussels were carried out at $6-10{ }^{\circ} \mathrm{C}$ and sent to Dipartimento di Sanità Pubblica, Patologia Comparata ed Igiene Veterinaria Agripolis, Università di Padova (Italia). From these in natura samples some strains of bacteria belonging to the Vibrio kind have been isolated according to the American Food and Drug Administration (FDA) guidelines (Bacteriological Analytical Manual - BAM). The samples were submitted to enrichment at Alkaline Peptone Water (APW) added of $1 \%$ of sodium chloride $(\mathrm{NaCl})$ and APW plus $3 \%$ $\mathrm{NaCl}\left(37^{\circ} \mathrm{C} / 18-24 \mathrm{~h}\right)$. Then, samples were streaked onto TCBS Agar (Thiossulfate Citrate Bile Sucrose Agar). The classification of bacteria isolated has been carried out using the API 20 E (Bio Mérieux) kits. The bacteria identified have been subsequently sent to the Laboratório de Referência Nacional de Cólera e outras Enteroinfecções Bacterianas (LRNCEB), Instituto Oswaldo Cruz (IOC), FIOCRUZ in Rio de Janeiro, to confirm the biochemical characterization of the species and to carry out the virulence tests ${ }^{2}$.

In Brazil, a total of 20 samples of Perna perna were collected, between January and February 2004, in Guanabara Bay (Rio de Janeiro) and analyzed at LRNCEB. Also, these in natura samples were submitted to the same enrichment described above and streaked onto TCBS Agar. The preliminary confirmation strains were carried out according to colonies behavior in LIA (Lysine Iron Agar) and TSI (Triple Sugar Iron Agar) allowing the Vibrio spp. presumptive differentiation. After, the cytochrome oxidase positive colonies were submitted to biochemical tests including resistance to $\mathrm{O} / 129$ vibriostatic agent (2,4 diamino 6-7 diisoprylpteridine), ONPG production (ortho-nitrophenyl- $\beta-D$ galactopyranoside), VP (Voges-Proskauer), lysine/ornithine descarboxylase and arginine dihydrolase and halophilic characteristics ( 0 to $10 \%$ of sodium chloride $)^{2}$.

The dermatopathogenicity of all strains of $V$. alginolyticus was analyzed for the presence of virulence factors represented by the three enzymes collagenolytic: elastases, collagenases and chondroitinases. The Vibrio alginolyticus strains were growth in BHI (Brain Heart Infusion) broth $\left(37^{\circ} \mathrm{C} / 18-24 \mathrm{~h}\right)$ and then streaked onto Agar BHI added with $1 \%$ of collagen, Agar BHI added with $1 \%$ of elastin and Agar BHI added with $0.04 \%$ chondroitin sulfate and $1 \%$ bovine serum (37 $\left.{ }^{\circ} \mathrm{C} / 18-24 \mathrm{~h}\right)$. The interpretative test was carried out in seven days considering positive colonies result as a clearing zone (translucent and luminous halo) under and around the spots inoculums ${ }^{2}$.

\section{RESULTS}

The results showed a total of 127 bacteria strains distributed in 15 different species of Vibrio (82.6\%), five Aeromonas species (15.74\%) and two Plesiomonas shigelloides $(1.57 \%)$. The main Vibrio isolated from mussels samples were Vibrio alginolyticus (32.4\%), V. harveyi (19\%), V. parahaemolyticus (7.6\%) and Vibrio spp. (18\%). Other species as $V$. carchariae, $V$. logei, V. mediterranei, V. damsela and V. anguillarum were also isolated as shown in Table 1 . Some species were isolated in low frequency $(<1 \%)$ as V. cholerae non O1, V. campbelli, V. fluvialis, V. gazogenes, V. metschnikovii, V. fisheri and V. aestuarinus.

Table 1

Distribution of Vibrios isolated from bivalve mollusks in Venice Lagoon (Italy) and Guanabara Bay (Brazil)

\begin{tabular}{|c|c|c|c|c|c|c|}
\hline \multirow[t]{2}{*}{ Microorganisms } & \multicolumn{2}{|c|}{$\begin{array}{l}\text { Venice } \\
\text { Lagoon }\end{array}$} & \multicolumn{2}{|c|}{$\begin{array}{c}\text { Guanabara } \\
\text { Bay }\end{array}$} & \multicolumn{2}{|c|}{ Total } \\
\hline & $\mathrm{n}$ & $(\%)$ & $\mathrm{n}$ & $(\%)$ & $\mathrm{n}$ & $(\%)$ \\
\hline Vibrio cholerae non $\mathrm{O} 1$ & 1 & 0.95 & & - & 1 & 0.95 \\
\hline Vibrio campbelli & & - & 1 & 0.95 & 1 & 0.95 \\
\hline Vibrio fluvialis & & - & 1 & 0.95 & 1 & 0.95 \\
\hline Vibrio gazogenes & & - & 1 & 0.95 & 1 & 0.95 \\
\hline Vibrio metschnikovii & & - & 1 & 0.95 & 1 & 0.95 \\
\hline Vibrio fischeri & & - & 1 & 0.95 & 1 & 0.95 \\
\hline Vibrio aestuarinus & & - & 1 & 0.95 & 1 & 0.95 \\
\hline Vibrio anguillarum & & - & 2 & 1.9 & 2 & 1.9 \\
\hline Vibrio damsela & & - & 2 & 1.9 & 2 & 1.9 \\
\hline Vibrio mediterranei & & - & 3 & 2.8 & 3 & 2.8 \\
\hline Vibrio logei & & - & 4 & 3.8 & 4 & 3.8 \\
\hline Vibrio carchariae & & - & 6 & 5.7 & 6 & 5.7 \\
\hline Vibrio parahaemolyticus & 2 & 1.9 & 6 & 5.7 & 8 & 7.6 \\
\hline Vibrio harveyi & & - & 20 & 19 & 20 & 19 \\
\hline Vibrio alginolyticus & 6 & 5.7 & 28 & 26.7 & 34 & 32.4 \\
\hline Vibrio spp. & 3 & 2.8 & 16 & 15.3 & 19 & 18 \\
\hline Total & 12 & 11.5 & 93 & 88.5 & 105 & 100 \\
\hline
\end{tabular}

Otherwise, the main Aeromonas isolated were Aeromonas sobria (18.2\%), A. veronii biogroup veronii (18.2\%), A. veronii biogroup sobria (18.2\%), A. caviae (13.6\%), A. hydrophila (13.6\%) and Aeromonas spp. (9\%) (Table 2).

A total of six Vibrio alginolyticus strains coming from the Venice Lagoon and 28 coming from the Guanabara Bay have been analyzed. Among the Italian strains we observed that four strains (11.8\%) produced all three enzymes: elastases (ELA), collagenases (COL) and chondroitinases (CHO); the other two (2.9\% each) produced only one enzyme: one elastases, the other one chondroitinases. Amongst the Brazilian strains we observed that 14 strains $(41 \%)$ produced the three enzymes altogether; 11 produced two enzymes (ELA-COL, ELA-CHO and $\mathrm{CHO}-\mathrm{COL})$. Amid these, four (11.8\%) produced elastases and 
Table 2

Distribution of Aeromonas and Plesiomonas shigelloides isolated from bivalve mollusks in Guanabara Bay (Brazil)

\begin{tabular}{lll}
\hline Microorganisms & $\mathrm{n}$ & $(\%)$ \\
\hline Aeromonas sobria & 4 & 18.2 \\
Aeromonas caviae & 3 & 13.6 \\
Aeromonas veronii biogroup veronii & 4 & 18.2 \\
Aeromonas veronii biogroup sobria & 4 & 18.2 \\
Aeromonas hydrophila & 3 & 13.6 \\
Aeromonas spp. & 2 & 9 \\
Plesiomonas shigelloides & 2 & 9 \\
\hline Total & $\mathbf{2 2}$ & $\mathbf{1 0 0}$ \\
\hline
\end{tabular}

Table 3

Frequency of virulence factors production (enzymes) from $V$. alginolyticus strains isolated in Italy and Brazil

\begin{tabular}{lcccccc}
\hline Enzymes Profiles & \multicolumn{5}{c}{ Vibrio } & \multicolumn{3}{c}{ alginolyticus strains } \\
& $\mathrm{n}$ & $(\%)$ & $\mathrm{n}$ & $(\%)$ & $\mathrm{n}$ & $(\%)$ \\
\hline ELA-COL-CHO & 4 & 11.8 & 14 & 41 & 18 & 53 \\
ELA-COL & & - & 4 & 11.8 & 4 & 11.8 \\
ELA-CHL & - & 4 & 11.8 & 4 & 11.8 \\
CHO-COL & - & 3 & 8.8 & 3 & 8.8 \\
COL & - & 1 & 2.9 & 1 & 2.9 \\
ELA & 1 & 2.9 & 1 & 2.9 & 2 & 5.8 \\
CHO & 1 & 2.9 & & - & 1 & 2.9 \\
No enzyme production & & - & 1 & 2.9 & 1 & 2.9 \\
\hline Total & $\mathbf{6}$ & $\mathbf{1 7 . 6}$ & $\mathbf{2 8}$ & $\mathbf{8 2 . 3}$ & $\mathbf{3 4}$ & $\mathbf{1 0 0}$ \\
\hline
\end{tabular}

$\mathrm{ELA}=$ elastases, $\mathrm{COL}=$ collagenases and $\mathrm{CHO}=$ chondrointinases.

collagenases and just as many elastases and chondroitinases, three produced CHO-COL $(8.8 \%)$. A strain did not produce any of the three enzymes (Table 3 ).

\section{DISCUSSION}

In this study the presence of Vibrionaceae and Aeromonadaceae families isolated from bivalves mollusks harvested in Italy and Brazil was, not surprisingly also present and considered as an important group of autochthonous pathogens inhabitant of marine environment and distributed worldwide ${ }^{7}$.

There was observed the frequency of certain Vibrio ( $V$. parahaemolyticus and $V$. cholerae non $\mathrm{O} 1)$ and Aeromonas species (A. hydrophila and A. sobria) related to foodborne outbreaks after the consuming of in natura or undercooked seafoods. Also, we observed the isolation of Plesiomonas shigelloides an emergent pathogen isolated from aquatic ecosystem including fresh and estuarine water. These pathogens may cause different pathologies especially to immunocompromised patients that are more susceptible to infections $s^{5,7}$.

Vibrio alginolyticus was the major specie isolated from the mussels analyzed showing the relevance to marine ecosystem particularly when associated to the risks for human health (handlers, fisheries, swimmers and seafood consumers) after exposure to aquatic environment. Moreover, the high incidence of this pathogen has been related to gastrointestinal and extraintestinal infections as otitis and cutaneous lesions in humans and animals. This epidemiological aspect is relevant specially to food chain and aquaculture professionals ${ }^{1,7}$.

Both in Venice Lagoon and Guanabara Bay, the majority of strains of Vibrio alginolyticus point to increasing virulence characteristics expressed by the presence of three enzymes at the same time while strains with low or null infectivity were minimal or absent in these cities $^{5}$.

There are several works dealing on extra cellular enzymes in waterborne (both salt- and fresh-water) bacteria. They include the investigation developed by RODRIGUES et al., (1992), who studied the pathogenicity of $V$. vulnificus from seawater and oyster from the state of Rio de Janeiro; RIBEIRO (1994), who analyzes enzymatic patterns in species of the Vibrio genus ( $V$. vulnificus, V. fluvialis, V. mimicus) isolated from seawater from the coast of the state of Rio de Janeiro; and PAVLOV et al., (2003), who studied several potentially pathogenic features of heterotrophic plate count bacteria (HPC) isolated from drinking water in South Africa. No studies have been found on pathogenicity of $V$. alginolyticus in bivalve molluscs from Rio de Janeiro, nor from the Lagoon of Venice ${ }^{6,8,9}$.

The results of these similar researches found non pathogenic $V$. vulnificus (absence of elastase, collagenase and chondroitinase enzymes) as the most common specie isolated but they did not describe the presence of elastase, collagenase and chondroitinase enzymes production at the same time in any $V$. vulnificus strain (the most common profile among our $V$. alginolyticus strains $)^{8,9}$.

These studies described the frequency of elastase, collagenase and chondroitinase among the strains analyzed. RIBEIRO (1994) found that the most common enzyme among Vibrio spp. strains was chondroitinase, present in $68.1 \%$ of analyzed strains. Others found the most common enzyme among V. vulnificus and HPC was elastase $(50 \%$ of V. vulnificus, $33 \%$ of HPC strains $)^{6,9}$. The latter results are in accordance with those we found in $V$. alginolyticus, although our bacteria produced elastase much more frequently: it is found in 23 of all Brazilian strains. Collagenase (22 strain productions) and chondroitinase (21 strain productions) are also more frequent among the bacteria we analyzed, than among those studied by others. These results show how $V$. alginolyticus, although often considered to be a low pathogenic or no-pathogenic species does have a considerable pathogenic potential, because of its capacity to produce pathogenic enzymes and because of its frequency, in both the Lagoon of Venice and Guanabara Bay.

However there may be several reasons why reported cases of dermatitis due to this bacteria are so scarce, e.g. the specificity of symptoms, which may lead to misidentification of pathogen causing dermatitis; little knowledge on the part of doctors about Vibrio dermatitis; the susceptibility of this bacteria to a great number of antibiotics, so often prescribed when any kind of infection occurs; and the low resistance of bacteria when exposed to air and sun. Further 


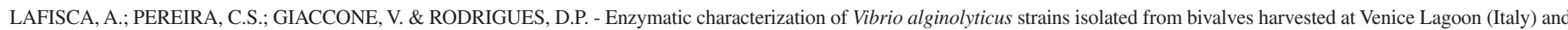
Guanabara Bay (Brazil). Rev. Inst. Med. trop. S. Paulo, 50(4): 199-202, 2008.

studies will be carried out to study these bacteria, analyzing the role of polluted environments on bacterial resistance to the most common antibiotics and to heavy metals ${ }^{6,8,9}$.

Molecular studies showed that Vibrio alginolyticus strains could acquire virulence factor genes by transduction between other marine bacterias. Then, $V$. alginolyticus can be a reservoir for virulence genes present in the aquatic environment. In spite of these premises, the clinical cases of reported human cutaneous vibriosis are insufficient both in the Venetian area and in Rio de Janeiro. Doctors' inadequate knowledge of this bacterium, the specificity of the symptoms correlated to it and its susceptibility to many antibiotics surely participate to the scarcity of cases of dermatitis reported ${ }^{3,10,11}$.

The occurrence of potential pathogens with or without virulence factors isolated in our investigation alert to their importance in Public Health and suggests the need to implant changes in hygiene and sanitary fields, particularly in practices involving handlers in order to prevent or control the multiplication of these pathogens in seafood or aquaculture systems.

\section{RESUMO}

\section{Caracterização enzimática de cepas de Vibrio alginolyticus isoladas de bivalves coletados na Lagoa de Veneza (Itália) e Baía de Guanabara (Brasil)}

O ecossistema aquático é o habitat natural de microrganismos incluindo aqueles dos gêneros Vibrio e Aeromonas os quais são patogênicos para o homem e animais. Na presente investigação foi avaliada a frequiência destas bactérias e a característica enzimática de 34 cepas de Vibrio alginolyticus isoladas de bivalves coletados na Lagoa de Venice (Itália) e Baía de Guanabara (Brasil) durante o período de Novembro-2003 a Fevereiro-2004. As amostras de mexilhões foram submetidas a enriquecimento em Água Peptonada Alcalina (APA) adicionada de $1 \%$ de Cloreto de Sódio $(\mathrm{NaCl})$ e APA com $3 \%$ de $\mathrm{NaCl}$ (37 $\left.{ }^{\circ} \mathrm{C} / 18-24 \mathrm{~h}\right)$. Em seguida as amostras foram semeadas em Agar TCBS (Agar Tiossulfato Citrato Bile Sacarose) e as colônias suspeitas foram submetidas à caracterização bioquímica. As cepas de Vibrio alginolyticus foram avaliadas quanto à produção das enzimas colagenase, elastase e condroitinase. Os resultados demonstraram o isolamento de 127 microrganismos assim distribuídos: 105 cepas de Vibrio das quais V. alginolyticus (32,4\%), V. harveyi $(19 \%)$ e $V$. parahaemolyticus (7,6\%), 20 cepas de Aeromonas e 2 Plesiomonas shigelloides foram os principais patógenos isolados. Observou-se a produção das três enzimas a partir de $V$. alginolyticus, consideradas principais fatores de virulência da bactéria, em especial em casos de infecção dermatológica humana.

\section{REFERENCES}

1. CARLI, A.; PANE, L.; CASARETO, L.; BERTONE, S. \& PRUZZO, C. - Occurrence of Vibrio alginolyticus in Ligurian Coast Rock Pools (Tyrrhenian Sea, Italy) and its association with the copepod Tigriopus fulvus (Fisher 1860). Appl. environ. Microbiol., 59: 1960-1962, 1993.

2. FOOD AND DRUG ADMINISTRATION (FDA) - Bacteriological analytical manual. On line version http://www.cfsan.fda.gov/ ebam/bam-9.html.

3. GONZÁleZ-ESCAlonA, N.; BlaCKSTONE, G.M. \& DePAOlA, A. Characterization of a Vibrio alginolyticus strain, isolated from Alaskan oysters, carrying a hemolysin gene similar to the thermostable direct hemolysin-related hemolysin gene (trh) of Vibrio parahaemolyticus. Appl. environ. Microbiol., 72: 7925-7929, 2006.

4. KOELLE, K.; PASCUAL, M. \& YUNUS, M. - Pathogen adaptation to seasonal forcing and climate change. Proc. biol. Sci., 272: 971-977, 2005.

5. MATTE, G.R.; MATTE, M.H.; SATO, M.I. et al. - Potentially pathogenic vibrios associated with mussels from a tropical region on the Atlantic coast of Brazil. J. appl. Bact., 77: 281-287, 1994.

6. PAVLOV, D.; WET, C.M.E.; GRABOW, W.O.K. \& EHLERS, M.M. - Potentially pathogenic features of heterotrophic plate count bacteria isolated from treated and untreated drinking water. Int. J. food Microbiol., 92: 275-287, 2004.

7. PEREIRA, C.S. - A cultura de mexilhões na Baía de Guanabara e suas implicações para a Saúde Pública. Contexto político-social e microbiológico. Rio de Janeiro, 2003. (Tese de Doutorado - Escola Nacional de Saúde Pública Sérgio Arouca)

8. RIBEIRO, R.V. - Caracterização de perfis enzimáticos em espécies do gênero Vibrio isoladas do litoral do município do Rio de Janeiro. Rio de Janeiro, 1994 (Dissertação de Mestrado - Universidade Federal Rural do Rio de Janeiro).

9. RODRIGUES, D.P.; RIBEIRO, R.V. \& HOFER, E. - Analysis of some virulence factors of Vibrio vulnificus isolated from Rio de Janeiro, Brazil. Epidemiol. Infect., 108: 463-467, 1992.

10. RODRIGUES, S.M.A.; GONÇALVES, E.G.R.; MELLO, D.M.; OLIVEIRA, E.G. \& HOFER, E. - Pesquisa de bactérias do gênero Vibrio em feridas cutâneas de pescadores do município de Raposa-MA. Rev. Soc. bras. Med. trop., 34: 407-411, 2001.

11. SCHMIDT, U.; CHMEL, H. \& COBBS, C. - Vibrio alginolyticus infections in humans. J. clin. Microbiol., 10: 666-668, 1979.

Received: 12 April 2007

Accepted: 10 April 2008 